\title{
Calcium-Induced Conformational Transition of Trout Ependymins Monitored by Tryptophan Fluorescence
}

\author{
Bernhard Ganss ${ }^{1,2}$ and Werner Hoffmann*,1,3 \\ ${ }^{I}$ Max-Planck-Institute for Psychiatry, Department of Neurochemistry, D-82152 Martinsried, Germany \\ ${ }^{2}$ CIHR Group in Matrix Dynamics, University of Toronto, Toronto, Ontario M5S 3E2, Canada \\ ${ }^{3}$ Institute of Molecular Biology and Medical Chemistry, Otto-von-Guericke-University, D-39120 Magdeburg, Germany
}

\begin{abstract}
Ependymins are secretory, calcium-binding sialoproteins which are the predominant constituents of the cerebrospinal fluid of many teleost fish. A bound form of these regeneration-responsive glycoproteins is associated with collagen fibrils of the extracellular matrix. Here, the tryptophan fluorescence of ependymins was monitored at various $\mathrm{Ca}^{2+}$ concentrations. Two distinct states were identified with a relatively sharp transition at about $1 \mathrm{mM} \mathrm{Ca}^{2+}$. In agreement with previous circular dichroism measurements, this strongly supports the hypothesis that a calcium-induced conformational change is important for the interaction of ependymins with components of the extracellular matrix. Such interactions with constituents of various basal laminae would also explain the important roles of piscine ependymins as well as invertebrate and mammalian ependymin-related proteins for cell adhesion processes and cell migration.
\end{abstract}

Keywords: Ependymins, MERP, calcium binding, extracellular matrix, tryptophan fluorescence, cell adhesion molecule, learning and memory.

\section{INTRODUCTION}

Ependymins are unique calcium-binding secretory proteins of the endomeninx of many teleost fish (for review, see [1]). Here, fibroblast-like cells synthesize these glycoproteins together with a number of extracellular matrix (ECM) molecules [1-4]. Fish ependymins are highly divergent [5-7]. The most conserved feature of piscine ependymins, other than the sequence F-E-E-G-V-X-Y-E/D-I/L-D between the two canonical $\mathrm{N}$-glycosylation sites [6], is the presence of sialic acid residues in the $\mathrm{N}$-linked sugar moiety [8]. As also shown for other extracellular proteins, e.g. fibrinogen [9], these acid structures are responsible for the calcium-binding capacity of ependymins [8].

An ependymin-related gene has been detected also in human where it is expressed mainly in brain, heart, and skeletal muscle. This gene was originally termed UCC1 because it is up-regulated in colon cancer [10]. Nowadays, this gene and its various mammalian homologs are named MERPs [11]. Ependymin-related genes are also present in invertebrate deuterostomes such as sea cucumbers [12] as well as protostomes [13]. Generally, there is only little amino acid sequence similarity between these ependyminrelated proteins. Strictly conserved are four cysteine residues, a tryptophan residue and a few other positions. Furthermore, all ependymin-related proteins contain at least one $\mathrm{N}$-glycosylation site.

Originally, piscine ependymins were detected when studying neuroplasticity in the goldfish (for review see [14]).

*Address correspondence to this author at the Institut für Molekularbiologie und Medizinische Chemie, Universitätsklinikum, Leipziger Str. 44, D39120 Magdeburg, Germany; Tel: +49-(391)-67-15 895; Fax: +49-(391)67-13 096; E-mail: werner.hoffmann@med.ovgu.de
Also interference of anti-sense ependymin-mRNA with memory consolidation has been reported [15]. However, ependymins are also attracting increasing interest because they share several characteristics with glycoproteins involved in cell contact phenomena [1]. For example, in the goldfish, infusion of ependymin antibodies blocks the sharpening of the regenerating retinotectal projection [16], and increased synthesis of ependymins in the optic nerve has been reported during its regeneration [17]. Generally, an anti-adhesive potential of ependymins would be in agreement with their synthesis in the endomeninx, where they could be responsible for a diffuse projection of posthatching retinal axons [1].

Soluble ependymins are the major protein constituents of the cerebrospinal fluid (CSF) of many teleost fish $[5,6,18$, 19]. Here they bind approximately $66 \%$ of the soluble $\mathrm{Ca}^{2+}$ (for example, trout CSF contains about $2.7 \mathrm{mM}$ soluble $\mathrm{Ca}^{2+}$ ) [8]. Interestingly, the expression of ependymins is strongly cold-induced [20]. A bound form of these glycoproteins is associated with the brain ECM, collagen fibrils being the predominant targets [4]. Thus far, the precise mode of interaction is not known. However, the calcium-binding capacity of ependymins [8] may be important for this association because self-assembly of the extracellular matrix is known to be $\mathrm{Ca}^{2+}$-dependent [21]. Circular dichroism (CD) measurements have revealed that binding of $\mathrm{Ca}^{2+}$ effects the conformation of trout ependymins by changing their tertiary but not their secondary structure [8]. The drastic change of the predominant signal at $288 \mathrm{~nm}$ is a strong indication that the single tryptophan residue at position 120 [5] is affected by this transition [8]. However, the CD measurements covered only the range up to $2 \mathrm{mM} \mathrm{Ca}^{2+}$ and a clear statement concerning the transition point was not possible with this method. 
Here, we report on extended studies where the tryptophan fluorescence of ependymins from the rainbow trout has been monitored at various $\mathrm{Ca}^{2+}$ concentrations. Ependymins from this quasi-tetraploid species are encoded by two homologous genes. Both gene products contain a single tryptophan residue [5] which is strictly conserved in ependymin sequences of all species analyzed thus far $[6,7]$.

\section{MATERIALS AND METHODS}

Ependymins $\left(\mathrm{M}_{\mathrm{r}}\right.$ on SDS polyacrylamide gel electrophoresis: $\approx 37 \mathrm{k}$ ) were purified from the CSF of rainbow trouts (Oncorhynchus mykiss) via a two step FPLC procedure using ion exchange and hydrophobic interaction chromatography as described previously [8]. Purified ependymins consisted of three glycoforms termed A, B, and C [5] where form A contributed to more than $95 \%$ and form $\mathrm{C}$ was detectable only in traces (data not shown).

Specific monitoring of the tryptophan fluorescence after excitation at $295 \mathrm{~nm}$ has been established as a method for the detection of conformational changes of proteins [22, 23]. Thus, $180 \mu \mathrm{g}$ FPL-purified trout ependymins were dissolved per $\mathrm{ml}$ of $14 \mathrm{mM} \mathrm{NaCl}, 10 \mathrm{mM}$ Tris/pH 7.4, $10 \mathrm{mM} \mathrm{CaCl}_{2}$ and a fluorescence spectrum was recorded with a RF-5000 spectrofluorometer (Shimadzu Deutschland GmbH, Duisburg, Germany) at $20^{\circ} \mathrm{C}$ using thermostat-controlled quartz cells (Hellma, Mühlheim, Germany) of 1-cm path length. Additionally, the fluorescence spectrum was recorded after complete complexation of $\mathrm{Ca}^{2+}$ by EDTA/pH 7.5. A maximum was observed for both $\mathrm{Ca}^{2+}$ concentrations at $335 \mathrm{~nm}$. Then, FPLC-purified trout ependymins were dissolved in 14 $\mathrm{mM} \mathrm{NaCl}, 10 \mathrm{mM}$ Tris/pH 7.4, $10 \mathrm{mM} \mathrm{CaCl}_{2}$. Different $\mathrm{Ca}^{2+}$ concentrations were titrated with various amounts of $\mathrm{EDTA} / \mathrm{pH}$ 7.5. After excitation at $295 \mathrm{~nm}$, the tryptophan fluorescence of each concentration point was measured at $335 \mathrm{~nm}$. The fluorescence at each concentration point was measured three times (after equilibration for $7 \mathrm{sec}$ ). Each relative fluorescence measured was corrected for its actual ependymin concentration. Two independent experimental series were carried out with trout ependymins.

\section{RESULTS AND DISCUSSION}

When ependymins at various $\mathrm{Ca}^{2+}$ concentrations were excited at $295 \mathrm{~nm}$, the corrected steady-state emission spectra originating from the single tryptophan residue were comparable in shape, as well as in the wavelength position of the maximum fluorescence intensity $\left(\lambda_{\max }=335-340 \mathrm{~nm}\right.$ ) (Fig. 1). In contrast, the relative intensities at $\lambda_{\max }$ varied at different $\mathrm{Ca}^{2+}$ concentrations.

Fig. (2) outlines the result of a typical experiment measuring the fluorescence at $335 \mathrm{~nm}$ as a function of the $\mathrm{Ca}^{2+}$ concentration. Generally, two states of ependymins are observed. There is a relatively sharp transition from the apo $\left(\mathrm{Ca}^{2+}\right.$-free $)$-proteins to the holo $\left(\mathrm{Ca}^{2+}\right.$-loaded $)$-proteins at about $1.0 \mathrm{mM} \mathrm{Ca}^{2+}$. Interestingly, this is very close to the free $\mathrm{Ca}^{2+}$ concentration in the trout CSF (which is about 0.9 $\mathrm{mM})$ and below the total $\mathrm{Ca}^{2+}$ concentration of trout CSF (which is about $2.7 \mathrm{mM}$ ) [8].

Thus, the holo-state can be considered as the native state of ependymins. Here, similarly to osteonectin/SPARC/BM40 [24-26], osteopontin, bone sialoprotein and BAG-75 [27],

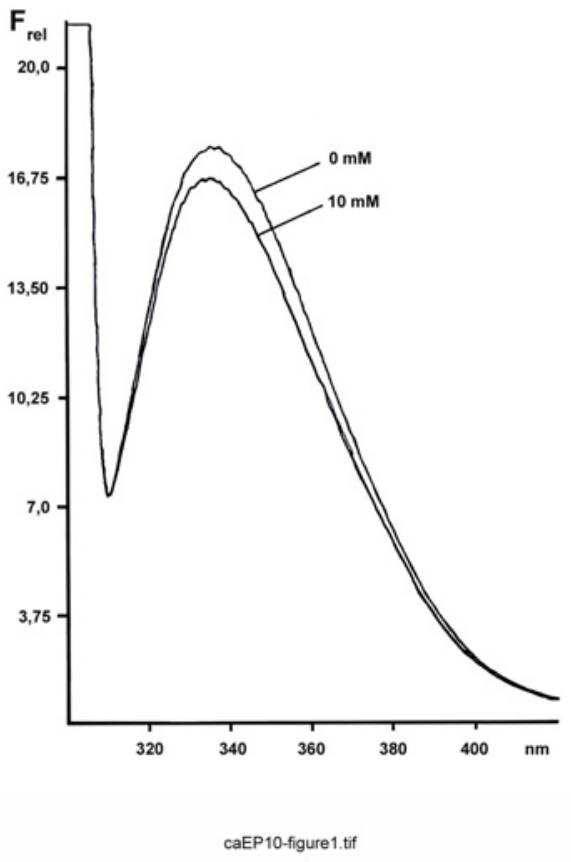

Fig. (1). Fluorescence spectrum of FPLC-purified ependymins from the rainbow trout. Shown is the relative emission fluorescence of trout ependymins $(180 \mu \mathrm{g} / \mathrm{ml})$ between 300 and $420 \mathrm{~nm}$ $\left(\mathrm{F}_{\text {rel }}\right.$, in arbitrary units; excitation at $\left.295 \mathrm{~nm}\right)$ at $10 \mathrm{mM} \mathrm{Ca}^{2+}$ and after complexation with EDTA.

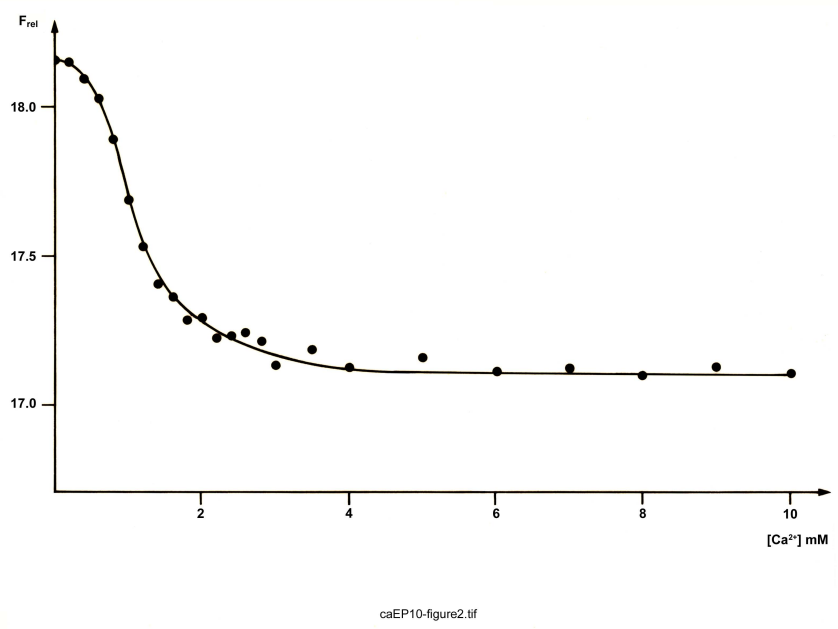

Fig. (2). Tryptophan fluorescence of FPLC-purified ependymins from the rainbow trout. Shown is the relative emission fluorescence of trout ependymins $(191 \mu \mathrm{g} / \mathrm{ml})$ at $335 \mathrm{~nm}\left(\mathrm{~F}_{\text {rel }}\right.$, in arbitrary units; excitation at $295 \mathrm{~nm}$ ) as a function of the $\mathrm{Ca}^{2+}$ concentration. Each point represents the mean of three measurements.

$\mathrm{Ca}^{2+}$ may trigger maintenance of a native structure which is essential for interaction with the ECM. Also aggregation of ependymins to naturally occurring multimers with $\mathrm{M}_{\mathrm{r}}$ of about 200k [28] may require $\mathrm{Ca}^{2+}$. This processes is particularly reminiscent of the aggregation of fibrinogen at physiological millimolar $\mathrm{Ca}^{2+}$ concentrations, where sialic acid residues represent the low affinity calcium-binding sites [9].

Whether the apo-state of ependymins is of any biological importance is not known thus far. As far as it is known it is always the $\mathrm{Ca}^{2+}$-bound state of a $\mathrm{Ca}^{2+}$-binding protein which 
is active [29]. Interestingly, there are multiple reports on severe fluctuations in the extracellular $\mathrm{Ca}^{2+}$ concentration of the brain [30-34]. They could locally be sufficient in order to affect ependymins. The precise nature of the apo-state has not been clarified currently. However, in contrast to a previous report [35], we have not succeeded in the precipitation of ependymins into insoluble aggregates solely by depletion of $\mathrm{Ca}^{2+}$. Consequently, we exclude that the apo-state represents an insoluble form of ependymins.

Taken together, the $\mathrm{Ca}^{2+}$-binding capacity of coldinduced ependymins would be in line with their postulated function for $\mathrm{Ca}^{2+}$ homeostasis in fish brain [20]. Furthermore, the results presented here extend our previous CD measurements which showed a $\mathrm{Ca}^{2+}$ dependent gradual change in the tertiary structure of trout ependymins with only a slight discontinuity at about $1 \mathrm{mM} \mathrm{Ca}^{2+}$ [8]. Interestingly, both this discontinuity and the sharp conformational transition observed by monitoring the tryptophan fluorescence occur at the same $\mathrm{Ca}^{2+}$ concentration. Thus, both studies indicate a $\mathrm{Ca}^{2+}$ dependent conformational change of ependymins. However, the tryptophan measurements reported here defined the transition point more clearly. These results also support our hypothesis that this conformational transition is essential for association of ependymins with ECM proteins presumably of collagen fibrils [8]. Thus, defining precisely the molecular mode of this interaction might be a crucial step for understanding the molecular function of piscine ependymins in the future.

Furthermore, the $\mathrm{Ca}^{2+}$-triggered conformational changes observed for piscine ependymins could also have some relevance for invertebrate and mammalian ependymin-related proteins. Generally, $\mathrm{Ca}^{2+}$-dependent interactions of ependymins/ependymin-related proteins and ECM proteins such as collagens would be perfectly designed to regulate cell adhesion and cell migration particularly on various basal laminae. This would explain why these enigmatic proteins play important roles for a variety of physiological and pathological processes such as neuronal regeneration and plasticity in fish (for review, see [1]), intestinal regeneration in sea cucumbers [12], tumorigenesis of the human colon [10], and remodeling of the respiratory mucosa in a murine asthma model [36].

\section{ACKNOWLEDGEMENTS}

We thank Dr. J. Stadlmüller and E. Weiher (Genzentrum, Munich) for their advice during the tryptophan fluorescence measurements and Dr. C. Falkner (Institut für Klinische Chemie, Munich) for her atomic absorption measurements.

\section{REFERENCES}

[1] Hoffmann, W.; Schwarz, H. Ependymins: meningeal-derived extracellular matrix proteins at the blood-brain barrier. Int. Rev. Cytol., 1996, 165, 121-158.

[2] Königstorfer, A.; Sterrer, S.; Hoffmann, W. Ependymins are expressed in the meninx of goldfish brain. Cell Tissue Res., 1990, 261, 59-64.

[3] Rinder, H.; Bayer, T.A.; Gertzen, E.-M.; Hoffmann, W. Molecular analysis of the ependymin gene and functional test of ist promoter region by transient expression in brachydanio rerio. DNA Cell Biol., 1992, 11, 425-432.

[4] Schwarz, H.; Müller-Schmid, A.; Hoffmann, W. Ultrastructural localization of ependymins in the endomeninx of the brain of the rainbow trout: possible association with collagen fibrils of the extracellular matrix. Cell Tissue Res., 1993, 273, 417-425.

[5] Müller-Schmid, A.; Rinder, H.; Lottspeich, F.; Gertzen, E.-M.; Hoffmann, W. Ependymins from the cerebrospinal fluid of salmonid fish: gene structure and molecular characterization. Gene, 1992, 118, 189-196.

[6] Müller-Schmid, A.; Ganß, B.; Gorr, T.; Hoffmann, W. Molecular analysis of ependymins from the cerebrospinal fluid of the orders Clupeiformes and Salmoniformes: no indication for the existence of an euteleost infradivision. J. Mol. Evol., 1993, 36, 578-585.

[7] Orti, G.; Meyer, A. Molecular evolution of ependymin and the phylogenetic resolution of early divergences among euteleost fishes. Mol. Biol. Evol., 1996, 13, 556-573.

[8] Ganss, B.; Hoffmann, W. Calcium binding to sialic acids and its effect on the conformation of ependymins. Eur. J. Biochem., 1993, 217, 275-280.

[9] Dang, C.V.; Shin, C.K.; Bell, W.R.; Nagaswami, C.; Weisel, J.W. Fibrinogen sialic acid residues are low affinity calcium-binding sites that influence fibrin assembly. J. Biol. Chem., 1989, 264, 15104-15108.

[10] Nimmrich., I.; Erdmann, S.; Melchers, U.; Chtarbova, S.; Finke, U.; Hentsch, S.; Hoffmann, I.; Oertel, M.; Hoffmann, W.; Müller, $\mathrm{O}$. The novel ependymin related gene $\mathrm{UCC} 1$ is highly expressed in colorectal tumor cells. Cancer Lett., 2001, 165, 71-79.

[11] Apostolopoulos, J.; Sparrow, R.L.; McLeod, J.L.; Collier, F.M. Darcy, P.K.; Slater, H.R.; Ngu, C.; Gregorio-King, C.C.; Kirkland, M.A. Identification and characterization of a novel family of mammalian ependymin-related proteins (MERPs) in hematopoietic, nonhematopoietic, and malignant tissues. DNA Cell Biol., 2001, 20, 625-635.

[12] Suárez-Castillo, E.C.; Medina-Ortíz, W.E.; Roig-López, J.L.; García-Arrarás, J.E. Ependymin, a gene involved in regeneration and neuroplasticity in vertebrates, is overexpressed during regeneration in the echinoderm Holothuria glaberrima. Gene, 2004, 334, 133-143.

[13] Suárez-Castillo, E.C.; García-Arrarás, J.E. Molecular evolution of the ependymin protein family: a necessary update. BMC Evol. Biol., 2007, 7, 23-42.

[14] Shashoua, V.E. The role of brain extracellular proteins in neuroplasticity and learning. Cell Mol. Neurobiol., 1985, 5, 183-207.

[15] Schmidt, R.; Brysch, W.; Rother, S.; Schlingensiepen, K.-H. Inhibition of memory consolidation after active avoidance conditioning by antisense intervention with ependymin gene expression. $\mathrm{J}$. Neurochem., 1995, 65, 1465-1471.

[16] Schmidt, J.T.; Shashoua, V.E. Antibodies to ependymin block the sharpening of the regenerating retinotectal projection in goldfish. Brain Res., 1988, 446, 269-284.

[17] Thormodsson, F.R.; Antonian, E.; Grafstein, B. Extracellular proteins of goldfish optic tectum labeled by intraocular injection of 3H-proline. Exp. Neurol., 1992, 117, 260-268.

[18] Königstorfer, A.; Sterrer, S.; Hoffmann, W. Biosynthesis of ependymins from goldfish brain. J. Biol. Chem., 1989, 264, 1368913692 .

[19] Hoffmann, W. Goldfish ependymins: cerebrospinal fluid proteins of meningeal origin. Prog. Brain Res., 1992, 91, 13-17.

[20] Tang, S.-J.; Sun, K.-H.; Sun, G.-H.; Lin, G.; Lin, W.-W.; Chuang, M.-J. Cold-induced ependymin expression in zebrafish and carp brain: implications for cold acclimation. FEBS Lett., 1999, 459, 9599.

[21] Yurchenco, P.D.; Schittny, J.C. Molecular architecture of basement membranes. FASEB J., 1990, 4, 1577-1590.

[22] Lakowicz, J.R. Principles of Fluorescence Spectroscopy, Plenum Press, New York, London, 1983.

[23] Hutnik, C.M.L.; MacManus, J.P.; Banville, D.; Szabo, A.G. Comparison of metal ion-induced conformational changes in parvalbumin and oncomodulin as probed by the intrinsic fluorescence of tryptophan 102. J. Biol. Chem., 1990, 265, 11456-11464.

[24] Engel, J.; Taylor, W.; Paulsson, M.; Sage, H.; Hogan, B. Calcium binding domains and calcium-induced conformational transition of SPARC/BM-40/osteonectin, an extracellular glycoprotein expressed in mineralized and nonmineralized tissues. Biochemistry, 1987, 26, 6958-6965.

[25] Sage, H.; Vernon, R.B.; Funk, S.E.; Everitt, E.A.; Angello, J. SPARC, a secreted protein associated with cellular proliferation, inhibits cell spreading in vitro and exhibits $\mathrm{Ca}^{2+}$-dependent binding to the extracellular matrix. J. Cell Biol., 1989, 109, 341-356. 
[26] Maurer, P.; Mayer, U.; Bruch, M.; Jenö, P.; Mann, K.; Landwehr, R.; Engel, J.; Timpl, R High-affinity and low-affinity calcium binding and stability of the multidomain extracellular 40-kDa basement membrane glycoprotein (BM-40/SPARC/osteonectin). Eur. J. Biochem., 1992, 205, 233-240.

[27] Chen, Y.; Bal, B.S.; Gorski, J.P. Calcium and collagen binding properties of osteopontin, bone sialoprotein, and bone acidic glycoprotein-75 from bone. J. Biol. Chem., 1992, 267, 24871-24878.

[28] Thormodsson, F.R.; Parker, T.S.; Grafstein, B. Immunochemical studies of extracellular glycoproteins (X-GPs) of goldfish brain. Exp. Neurol., 1992, 118, 275-283.

[29] Maurer, P.; Hohenester, E. Structural and functional aspects of calcium binding in extracellular matrix proteins. Matrix Biol., 1997, 15, 569-580.

[30] Nicholson, C. Modulation of extracellular calcium and its functional implications. Fed. Proc., 1980, 39, 1519-1523.

[31] Benninger, C.; Kadis, J.; Prince, D. A. Extracellular calcium and potassium changes in hippocampal slices. Brain Res., 1980, 187, 165-182.
Krnjevic, K.; Morris, M.E.; Reiffenstein, R.J. Stimulation-evoked changes in extracellular $\mathrm{K}^{+}$and $\mathrm{Ca}^{2+}$ in pyramidal layers of the rat's hippocampus. Can. J. Physiol. Pharmacol., 1982, 60, 1643-1657.

[33] Pumain, R; Heinemann, U. Stimulus- and amino acid-induced calcium and potassium changes in rat neocortex. J. Neurophysiol., 1985, 53, 1-14

[34] Pumain, R.; Kurcewicz, I.; Louvel, J. Ionic changes induced by excitatory amino acids in the rat cerebral cortex. Can. J. Physiol. Pharmacol., 1987, 65, 1067-1077.

[35] Shashoua, V.E. Monomeric and polymeric forms of ependymin: a brain extracellular glycoprotein implicated in memory consolidation processes. Neurochem. Res., 1988, 13, 649-655.

[36] Kouznetsova, I.; Chwieralski, C.E.; Bälder, R.; Hinz, M.; Braun, A.; Krug, N.; Hoffmann, W. Induced trefoil factor family 1 expression by trans-differentiating Clara cells in a murine asthma model. Am. J. Respir. Cell Mol. Biol., 2007, 36, 286-295.

(C) Ganss and Hoffmann; Licensee Bentham Open.

This is an open access article licensed under the terms of the Creative Commons Attribution Non-Commercial License (http://creativecommons.org/licenses/by-nc/3.0/) which permits unrestricted, non-commercial use, distribution and reproduction in any medium, provided the work is properly cited. 